\title{
DEMONSTRATION OF COLOSTRAL ANTIBODIES IN THE NASAL SECRETIONS OF CALVES AND THEIR PROTECTIVE EFFECT AGAINST INFECTION
}

\author{
Z. POSPÍŠIL, J. KREJČÍ* and L. RODÁK \\ Veterinary Research Institute, 62132 Brno, *District Veterinary Centre, Tachov
}

Received, fune 18, 1982

\begin{abstract}
Pospíšil Z., J. Krejčí, L. Rodák: Demonstration of Colostral Antibodies in the Nasal Secretions of Calves and Their Protective Effect against Infection. Acta vet. Brno, 52, 1983: 59-65.

This report demonstrated the transfer of specific colostral antibodies against infectious bovine rhinotracheitis (IBR) virus to respiratory tract secretions in newborn calves. The colostral antibodies appeared in the blood sera and nasal secretions as early as the 1st day after ingestion of colostrum; the results of examination before ingestion of colostrum were invariably negative. The antibody titres in nasal secretions did not generally exceed $1: 8$ (those found in the colostrum, dam sera and calf sera reached $1: 128$ to $1: 256$ ) and could be demonstrated, for the most part, only up to 15 to 20 days after birth and rarely longer. The immunoglobulins of the nasal secretions were almost exclusively IgG 1 by radioimmunoassay. Their protective effect against IBR virus was demonstrated by experimental infection.
\end{abstract}

Colostrum, antibody, nasal secretion, local effect, immunoglobulin $\operatorname{IgG} 1, I B R$ virus.

Studies on the defence mechanisms operating in respiratory infections of man and animals have paid much attention to the local effect of antibody contained in mucosal secretions. Most of these studies, however, have been focused mainly on active immunity, particularly the production of local antibodies, the site of their development, the ratio of individual immunoglobulin classes, the relation of serum and local antibodies and their protective effect after previous infection or vaccination (Marshall and Frank 1975; Asso and Le Jan 1978; Lupton 1980; Clover and Zarkower 1980; a.o.).

Only few studies have been concerned with passive protection of the respiratory tract (Menšik et al. 1971a; Wells et al. 1975; Charley and Carthier 1977), although evidence was presented to indicate that both piglets and calves from dams having a high content of antibodies against respiratory viruses and bacteria in their colostrum generally do not become ill in the first weeks after birth (Menšík et al. 1971b; Smith et al. 1976).

Since the epitheliochorial placenta of cattle and pigs does not allow transplacental transfer of immunoglobulins to the foetus, and newborn animals are practically agammaglobulinaemic at birth, the passive transfer of immunity from dam to offspring through colostrum is the first and most important prerequisite for the health of the offspring in the first days after birth. This is confirmed, among other things, by the differences in susceptibility to various infections between colostrum-fed and colostrum-deprived calves (Oudar et al. 1976; Clover and Zarkower 1980).

Colostral antibodies circulating in the bloodstream are of particular importance in diseases affecting the whole body, such as colisepsis, salmonelloses, pasteurelloses, a.o. (Fey and Margadant 1961; Oudar et al. 1976; Salajka 1980). On the other hand, in infections where the pathogenic effect of microorganisms is localized mainly to the mucosa, the presence of specific antibodies at the site of infection is indispensable. In these cases the role of serum antibodies is less important. This is also evidenced by the disproportion between blood serum virus-neutralizing antibody titres and the protection of calves against respiratory infections (Frank and Marshall 1971). Considering that neither systemic nor local active immunity can be expected to be present in the 
first days after birth, it can be assumed that the protective function even on the respiratory mucosa of newborn animals will be secured, for the most part, by colostral antibodies which arrive there from the bloodstream.

To elucidate the possibilities of the transfer of colostral antibodies to respiratory secretions and to gain an insight into the laws governing this transfer, we chose antibodies against infectious bovine rhinotracheitis (IBR) virus, which can be detected with relative ease, and followed their dynamics in the sera and nasal secretions of newborn calves and investigated their protective effect agains experimental infection.

\section{Materials and Methods}

\section{Experimental animals}

The dynamics of colostral antibodies in the sera and nasal secretions of newborn calves were followed in a herd where natural antibodies against IBR virus had been appearing for some time without clinical manifestations of the disease. About half a year before the start of the experiment some cows were vaccinated with an inactivated vaccine against IBR virus (BORINAK, Bioveta Nitra) to test its immunogenic activity. The titres of virus-neutralizing antibodies after vaccination and revaccination averaged $1: 64$ to $1: 128$, and some non-vaccinated cows were without antibodies. A total of 34 dam-calf pairs from this herd were included in the experiment.

\section{Collection of Specimens}

Samples of blood and colostrum were collected from cows on the day of parturition for serological demonstration of specific antibodies against IBR virus. In newborn calves blood samples were withdrawn and nasal secretions were collected by means of gauze tampoons for serological examination before ingestion of colostrum and then after ingestion of colostrum daily, where possible, during the first week and then at 3- to 4-day intervals up to 28 to 45 days of age.

Tampoons were left in the nasal cavities for approximately 20 minutes to ensure their imbibition. The nasal secretions were obtained either by expressing the fluid or by centrifugation of the tampoons in test tubes.

Colostrum samples for the demonstration of antibodies were allowed to curdle overnight at room temperature and were then centrifuged at $3000 \mathrm{rpm}$. The examination itself was carried out on colostral whey.

\section{Methods of Examination}

Serological examination of the blood sera, nasal secretions and colostra was performed with the virus-neutralization test in a microsystem (Pospíšil et al. 1979). Class determination of immunoglobulins against IBR virus in the samples was made by a radioimmunoassay using ${ }^{125}$ I-labelled class-specific antibodies (Rodák et al. 1980).

\section{Experimental Infection}

To test the protective effect of specific colostral antibodies, 4 immune calves without antibodies were infected intranasally at 4 to 7 days of age with IBR virus, strain TI, in its 17th passage in calf kidney cells using $5 \mathrm{ml}$ doses with the infectivity titre of $10^{5} \mathrm{TCID}_{50}$. The calves were observed for clinical signs of disease, and attempts were made to recover the virus.

\section{Results}

The titre of antibodies against IBR virus in the colostrum corresponded, for the most part, to the titre of antibodies in cows' serum. Only in one cow the titre of serum antibodies was $1: 64$, but that of colostral antibodies merely $1: 4$.

Serological examination of precolostral sera did not detect specific antibodies against IBR virus in any of the samples. After ingestion of colostrum, the blood serum antibody titres rose markedly and then declined gradually. Nevertheless, specific antibodies were still detectable 7 weeks after birth, at which time the last blood samples were collected from some calves. The results including some cow-calf pairs are presented in Table 1. 
Table 1

Dynamics of colostral antibodies in the sera and nasal secretions of calves

\begin{tabular}{|c|c|c|c|c|}
\hline \multirow{2}{*}{$\begin{array}{l}\text { Dam-calf } \\
\text { pair No. }\end{array}$} & \multirow{2}{*}{ Specimen } & \multirow{2}{*}{$\begin{array}{c}\text { Date of } \\
\text { collection }\end{array}$} & \multicolumn{2}{|c|}{ Antibody titre } \\
\hline & & & $\begin{array}{l}\text { in serum or } \\
\text { colostrum }\end{array}$ & $\begin{array}{l}\text { in nasal } \\
\text { secretion }\end{array}$ \\
\hline 1 & $\begin{array}{l}\text { Cow serum } \\
\text { Colostrum } \\
\text { Precolostral serum } \\
\text { Postcolostral serum } \\
\text { Postcolostral serum } \\
\text { Postcolostral serum } \\
\text { Postcolostral serum } \\
\text { Postcolostral serum } \\
\text { Postcolostral serum } \\
\text { Postcolostral serum } \\
\text { Postcolostral serum }\end{array}$ & $\begin{array}{l}25 \text { April } \\
25 \text { April } \\
25 \text { April } \\
26 \text { April } \\
4 \text { May } \\
12 \text { May } \\
17 \text { May } \\
24 \text { May } \\
1 \text { June } \\
7 \text { June } \\
\text { 20 June }\end{array}$ & $\begin{array}{l}1: 128 \\
1: 128 \\
\text { neg. } \\
1: 128 \\
1: 64 \\
1: 32 \\
1: 16 \\
1: 16 \\
1: 8 \\
1: 8 \\
1: 8\end{array}$ & $\begin{array}{l}- \\
- \\
\text { neg. } \\
1: 8 \\
1: 4 \\
1: 2 \\
\text { neg. } \\
\text { neg. } \\
\text { neg. } \\
\text { neg. } \\
\text { neg. }\end{array}$ \\
\hline 2 & $\begin{array}{l}\text { Cow serum } \\
\text { Colostrum } \\
\text { Precolostral serum } \\
\text { Postcolostral serum } \\
\text { Postcolostral serum } \\
\text { Postcolostral serum } \\
\text { Postcolostral serum } \\
\text { Postcolostral serum } \\
\text { Postcolostral serum } \\
\text { Postcolostral serum }\end{array}$ & $\begin{array}{r}29 \text { April } \\
29 \text { April } \\
29 \text { April } \\
2 \text { May } \\
5 \text { May } \\
8 \text { May } \\
12 \text { May } \\
17 \text { May } \\
24 \text { May } \\
1 \text { June }\end{array}$ & $\begin{array}{l}1: 64 \\
1: 64 \\
\text { neg. } \\
1: 64 \\
1: 64 \\
1: 64 \\
1: 32 \\
1: 32 \\
1: 32 \\
1: 16\end{array}$ & $\begin{array}{l}- \\
- \\
\text { neg. } \\
1: 8 \\
1: 4 \\
1: 2 \\
1: 2 \\
\text { neg. } \\
\text { neg. } \\
\text { neg. }\end{array}$ \\
\hline 3 & $\begin{array}{l}\text { Cow serum } \\
\text { Colostrum } \\
\text { Precolostral serum } \\
\text { Postcolostral serum } \\
\text { Postcolostral serum } \\
\text { Postcolostral serum }\end{array}$ & $\begin{array}{l}29 \text { April } \\
29 \text { April } \\
29 \text { April } \\
5 \text { May } \\
12 \text { May } \\
24 \text { May }\end{array}$ & $\begin{array}{l}\text { neg. } \\
\text { neg. } \\
\text { neg. } \\
\text { neg. } \\
\text { neg. } \\
\text { neg. }\end{array}$ & $\begin{array}{l}- \\
\text { neg. } \\
\text { neg. } \\
\text { neg. } \\
\text { neg. }\end{array}$ \\
\hline 4 & $\begin{array}{l}\text { Cow serum } \\
\text { Colostrum } \\
\text { Precolostral serum } \\
\text { Postcolostral serum }\end{array}$ & $\begin{array}{l}30 \text { April } \\
30 \text { April } \\
30 \text { April } \\
6 \text { May }\end{array}$ & $\begin{array}{l}1: 128 \\
1: 256 \\
\text { neg. } \\
1: 2\end{array}$ & $\begin{array}{c}- \\
- \\
\text { neg. } \\
\text { neg. } \\
\text { (died } 8 \text { May) }\end{array}$ \\
\hline 5 & $\begin{array}{l}\text { Cow serum } \\
\text { Colostrum } \\
\text { Precolostral serum } \\
\text { Postcolostral serum } \\
\text { Postcolostral serum }\end{array}$ & $\begin{array}{l}29 \text { April } \\
29 \text { April } \\
29 \text { April } \\
2 \text { May } \\
5 \text { May }\end{array}$ & $\begin{array}{l}1: 64 \\
1: 4 \\
\text { neg. } \\
1: 4 \\
1: 4\end{array}$ & $\begin{array}{c}- \\
\text { neg. } \\
\text { neg. } \\
\text { neg. } \\
\text { (died } 6 \text { May) }\end{array}$ \\
\hline
\end{tabular}

Serological examination of the nasal secretions collected from calves before ingestion of colostrum also yielded invariably negative results. Specific antibodies against IBR virus could be demonstrated in them as early as the 1st day after ingestion of colostrum, although their titre was by far not as high as in the blood serum and did not exceed $1: 8$. Whereas the blood serum antibody titres declined slowly, the antibodies in nasal secretions fell rather rapidly in titre and could be detected only up to 15 to 20 days after birth (Table 1, Fig. 1). Only in one case where antibodies titres in both the blood and nasal secretions continued to rise up to the 3rd day after birth, the antibodies in nasal secretions also persisted for more than 28 days.

The determination of immunoglobulin classes by the radioimmunoassay using ${ }^{125}$ I-labelled class-specific antibodies showed that the immunoglobulins against IBR virus in the serum and colostrum of cows were mainly $\operatorname{IgG} 1$ and to a smaller 
extent IgG 2, whereas IgA and $\operatorname{Ig} M$ classes were represented quite negligibly. The examination of the nasal secretions of calves after ingestion of colostrum showed that the immunoglobulins involved were almost exclusively IgG 1, whereas $\operatorname{IgM}$ and $\operatorname{IgA}$ classes were not demonstrated at all.
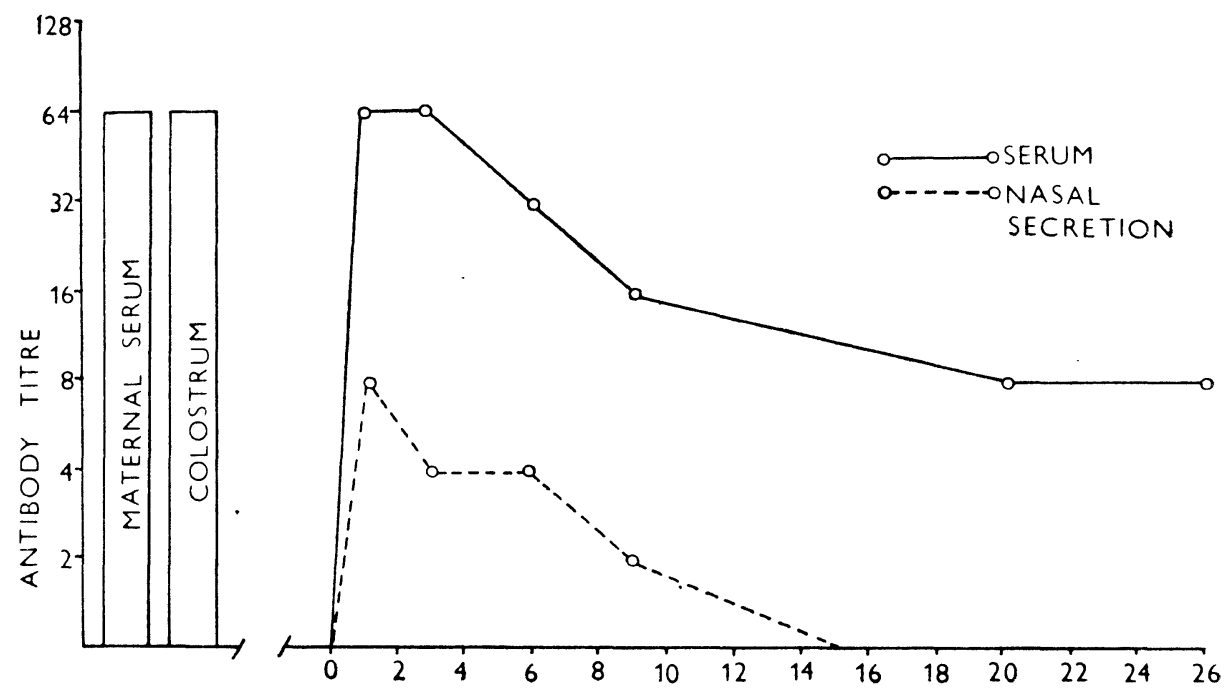

DAYS AFTER BIRTH

Fig. 1. Dynamics of specific antibodies against IBR virus in a calf after ingestion of colostrum

Table 2

Experimental infection of calves with IBR virus

\begin{tabular}{|c|c|c|c|c|c|}
\hline \multirow{2}{*}{$\begin{array}{l}\text { Calf } \\
\text { No. }\end{array}$} & \multicolumn{2}{|c|}{ Specific antibodies } & \multirow{2}{*}{$\begin{array}{c}\text { Maximum body } \\
\text { temperature }\end{array}$} & \multirow{2}{*}{$\begin{array}{l}\text { Clinical } \\
\text { signs }\end{array}$} & \multirow{2}{*}{$\begin{array}{l}\text { Virus } \\
\text { recovery }\end{array}$} \\
\hline & Blood & Nose & & & \\
\hline $\begin{array}{l}1 \\
2 \\
3 \\
4\end{array}$ & $\begin{array}{ll} & 0 \\
1 & : 128 \\
1 & : 64 \\
1 & : 16\end{array}$ & $\begin{array}{c}0 \\
1: 8 \\
1: 8 \\
1: 2\end{array}$ & $\begin{array}{l}40.1 \\
39.5 \\
39.5 \\
39.9\end{array}$ & $\begin{array}{l}+ \\
0 \\
0 \\
\pm\end{array}$ & $\begin{array}{l}++ \\
0 \\
0 \\
+\end{array}$ \\
\hline $\begin{array}{l}5 \\
6\end{array}$ & $\begin{array}{l}0 \\
1: 128\end{array}$ & $\begin{array}{c}0 \\
1: 8\end{array}$ & $\begin{array}{l}40.7 \\
39.6\end{array}$ & $0^{++}$ & $0^{++t}$ \\
\hline
\end{tabular}

Experimental infection with IBR virus resulted only in a mild and transient temperature elevation in 2 of the 4 immune calves, but produced the typical respiratory syndrome with a temperature rise to $40.1^{\circ}$ and $40.7^{\circ} \mathrm{C}$ in the 2 non-immune calves. IBR virus was recovered from 1 immune calf 5 to 7 days after infection, at which time antibodies in the nasal secretions had waned, but antibodies in the blood serum persisted. The two calves without antibodies yielded virus from the 1 st to the 7 th day after infection (Table 2). 


\section{Discussion}

The investigation into the dynamics of colostral antibodies in the sera and nasal secretions of calves showed that after ingestion of colostrum these antibodies not only appeared in the blood serum, but were also secreted on the respiratory tract mucosa.

The colostral origin of antibodies in the nasal secretions is evidenced by the absence of antibodies from all the samples examined before ingestion of colostrum and their demonstration in the nasal secretions after ingestion of colostrum. Similarly, the demonstration of the same IgG 1 immunoglobulin class in the nasal secretions of newborn calves and in the colostrum of their dams can be taken as evidence of the passive transfer of antibodies from colostrum to the mucosa, since actively produced secretory antibodies are represented almost exclusively by the IgA class (Turner 1977; Tomási et al. 1980).

Although it is well established that the bovine foetus is immunologically competent from approximately 100 days of gestation, depending of the type of antigenic stimulation (Butler 1973; Osburn 1973; Osburn et al. 1974), the newborn calf that has not come into contact with the respective antigen before requires always a certain length of time to develop active immunity. The demonstration of antibodies in the nasal secretions as early as the first day after birth excludes this possibility.

The present results confirm the observation of Menšík et al. (1971a) who demonstrated the transfer of colostral antibodies against swine influenza in lung washings of piglets and showed their protective effect against experimental infection. Wells et al. (1975) confirmed the presence of colostral antibodies in the nasal secretions of newborn lambs and found, as we did in calves, that the antibodies transferred to the respiratory mucosa were mainly IgG 1.

In contrast, Charley and Carthier (1977) failed to demonstrate the transfer of either colostral antibodies or parenterally administered antibodies against swine fever to tracheobronchial secretions. As they admit, however, this was probably due to the fact that their attempt at antibody demonstration was not made until 44 days after birth. At this time colostral antibodies in nasal secretions could not be demonstrated in our study either. In our view, the maximum of colostral antibody secretion on the respiratory tract mucosa occurs already in the first days after birth and the antibody titres then decline owing to biological degradation and steady dilution with mucosal secretions. In our study, antibodies were demonstrated in the secretions, on average, for 15 to 20 days and very rarely longer.

The results of experimental infection with IBR virus show that specific antibodies on the respiratory mucosa have a protective effect and it can be assumed that newborn animals can be protected from natural infection in the same way.

The significance of colostral antibodies emerges also from the death of 2 calves that had very low levels of specific antibodies in the blood and zero values in the nasal secretions (calves Nos. 4 and 5 in Table 1). Whether it was a case of a probable disturbance in immunoglobulin resorption or insufficient ingestion of colostrum (the colostrum had a high content of specific IBR antibodies) in calf No. 4 or of insufficient immunoglobulin secretion by the mammary gland (the colostrum contained specific antibodies only in a very low titre) in calf No. 5 , it can be assumed that there were similarly low or zero values for non-specific immunoglobulins and that the calves were therefore not protected against sepsis of which they eventually died. 
The concept of the protection of newborn calves would be incomplete if cell-mediated immunity were not taken into account (Asso and Le Jan 1978; Clover and Zarkower 1980). However, as pointed out by Osburn et al. (1974), the cell-mediated immunity of newborn calves is suppressed by glucocorticoid production associated with parturition and according to McGuire et al. (1976) the response to antigenic stimulation requires at least several days before a sufficient number of sensitized lymphocytes is produced.

In the light of these observations it can be concluded that colostral antibodies remain the most important means of protection against neonatal infections in the first days after birth and that antibodies secreted on the respiratory tract mucosa can protect newborn calves from respiratory infections.

\section{Průkaz kolostrálních protilátek v nosních sekretech telat a jejich ochranný účinek před infekcí}

U novorozených telat byl prokázán přestup specifických kolostrálních protilátek proti viru IBR do sekretù respiračního traktu. Kolostráiní protilátky se objevily v krevních sérech a nosních sekretech již 1 . den po napití kolostra, přičemž vyšetření před podáním kolostra bylo vžciy negativní. Titry protilátek $\mathrm{v}$ nosních sekretech většinou nepřesahovaly ředění $1: 8$ (v kolostrech, sérech matek a sérech telat dosahovaly až $1: 128-256)$ a bylo je možno prokazovat převážně jen do 15. až 20. dne po narození, zřídka déle. Radioimunologicky byly v nosních sekretech prokazovány téměř výhradně imunoglobuliny tř́ídy IgG 1. Byl prokázán jejich ochranný účinek proti experimentální infekci virem IBR.

\section{Доказательство молозивных антител с секрете носа телят и их противоинфекционное защитное воздействие}

У новорожденных телят был установлен переход специфических молозивных антител против вируса IBR в секреты дыхательных путей. Молозивные антитела появились в кровяной сыворотке и секретах носа уже в первый день после потребления молозива. При этом исследования перед подачей молозива были всегда отрицательными. Титры антител в секретах носа в большинстве случаев не превышали разбавления 1:8 (в молозиву, сыворотке матерей и сыворотке телят они достигали $1: 128$ - 256) и их устанавливали преимущественно лишь до $15-20$ суток после рождения, изродка в более длительные сроки. В носовых секретах радиоиммунологически были установлены почти исключительно иммуноглобулины категории IgG 1. Было установ.гено их защитное действие от экспериментальной инфекции вируссом IBR.

\section{References}

ASSO, J. - LE JAN, C.: Viral infections of the respiratory tract of calves: Local immunity. Vet. Sci. Commun., 1, 1978: 297-305.

BUTLER, J. E.: Synthesis and distribution of immunoglobulins. J. Am. vet. med. Ass., 163, 1973: $795-798$.

CHARLEY, B. - CORTHIER, G.: Local immunity in the pig respiratory tract. II. Relationship of serum and local antibodies. Annls. microbiol. Inst. Pasteur., 128 B, 1977: 109-119.

CLOVER, C. K. - ZARKOWER, A.: Immunologic responses in colostrum-fed and colostrum-deprived calves. Am. J. vet. Res., 41, 1980: 1002-1007. 
FEY, H. - MARGADANT, A.: Hypogammaglobulinaemie bei der Colisepsis des Kalbes. Pathologia Microbiol., 24, 1961: 970-976.

FRANK, G. H. - MARSHALL, R. G.: Relationship of serum and nasal secretion-neutralizing antibodies in protection of calves against parainfluenza-3 virus. Am. J. vet. Res., 32, 1971: $1707-1715$.

LUPTON, H. W. - REED, D. E.: Clearance and shedding of infectious bovine rhinotracheitis virus from the nasal mucosa of immune and nonimmune calves. Am. J. vet. Res., 41, 1980: $117-119$.

MARSHALL, R. G. - FRANK, G. H.: Clinical and immunologic responses of calves with colostrally acquired maternal antibody against parainfluenza-3 virus to homologous viral infection. Am. J. vet. Res., 36, 1975: 1085-1090.

McGUIRE, T. C. - PFEIFFER, N. E. - WEIKEL, J. M. - BARTSCH, R. C.: Failure of colostral immunoglobulin transfer in calves dying from infectious disease. J. Am. vet. med. Ass., 169, 1976: 713-718.

MENŠÍK, J. - POSPÍŠIL, Z. - FRANZ, J. - DRESLEROVÁ, Z.: Local effect of passively acquired colostral antibody on the development of experimental swine influenza infection in suckling pigs. Zbl. VetMed., B 18, 1971a: 804-818.

MENŠÍK, J. - FRANZ, J. - POSPÍŠIL, Z. - KREJČÍ, J.: The local role of antibodies in the protection of calves and piglets against viral respiratory infections. Acta vet. Brno; Suppl. 2, 1971b: $75-81$.

OBBURN, B. I.: Immune responsiveness of the fetus and neonate. J. Am. vet. med. Ass., 163, 1973: $801-803$.

OSBURN, B. I. - STABENFELDT, G. H. - ARDANS, A. A. - TRESS, C. - SAWYER, M.: Perinatal immunity in calves. J. Am. vet. med. Ass., 164, 1974: 295-298.

OUDAR, J. - LARVOR, P. - DARDILLAT, J. - RICHARD, Y.: L'immunité d'origine colostrale chez le veau. Rev. med. vet., 127, 1976: 1309-1346.

POSPÍŚIL, Z. - MENŠÍK, J. - KREJČ́́, J.: Demonstration of infectious bovine rhinotracheitis virus in newborn colostrum-deprived calves with particular reference to its epizootiological significance. Zbl. VetMed., B 26, 1979: 325-335.

RODÁK, L. - POSPÍŠIL, Z. - HAMPL, J.: A study of the production of class-specific antibodies to infectious bovine rhinotracheitis (IBR) virus in calves using a solid-phase radioimmunoassay. Zbl. VetMed., B, 1983, (in press).

SALAJKA, E.: Koliinfekce telat a možnosti jejich specifické prevence. Acta Univ. agric. Fac. agr., 28, 1980: $335-338$.

SMITH, W. D. - WELLS, P. W. - BURRELLS, C. - DAWSON, A., McL.: Maternal immunoglobulins and parainfluenza- 3 virus inhibitors in the nasal and lacrimal secretions and serum of newborn lambs. Clin. exp. Immunol., 29, 1976: 544-553.

TOMÁSI, T. B. - LARSON, L. - CHALLACOMBE, S. - McNAAB, P.: Mucosal immunityorigin and migration patterns of cells in the secretory system. J. Allergy clin. Immun., 65, 1980: $12-19$.

TURNER, M. W.: The immunoglobulins. In: HOLBOROW, E. J. - REEVES, W. G.: Immunology in medicine. Acad. Press, London, 1979: 82-129.

WELLS, P. W. - DAWSON, A. McL. - SMITH, W. D. - SMITH, B. S. W.: Transfer of IgG from plasma to nasal secretions in newborn lambs. Vet. Rec., 97, 1975: 455. 